\title{
Large-scale characteristics of the distribution of blowing-snow sublimation
}

\author{
Konosuke SUGIURA, Tetsuo OHATA \\ Institute of Observational Research for Global Change, Japan Agency for Marine-Earth Science and Technology, \\ 2-15 Natsushima-cho, Yokosuka 237-0061, Japan \\ E-mail: sugiura@jamstec.go.jp
}

\begin{abstract}
To consider the large-scale characteristics of blowing-snow sublimation and its importance in the hydrological cycle in the cryosphere, we investigated the sublimation of blowing snow particles on a global scale using the global datasets of the European Centre for Medium-Range Weather Forecasts (ECMWF) re-analysis data and the International Satellite Land Surface Climatology Project (ISLSCP) Initiative I data for 1987. The sublimation fluxes of blowing snow particles were estimated globally with $2.5^{\circ}$ resolution at 6 hour intervals. We found that the sublimation of blowing snow particles occurs more widely in the Northern Hemisphere than in the Southern Hemisphere, does not increase monotonously with latitude, and becomes more active in the polar coast regions and highlands, although the annual mean sublimation fluxes of the Northern and Southern Hemispheres are almost equal. In addition, we confirmed the characteristic seasonal changes in the area of sublimation in the Northern Hemisphere. Although we need to incorporate continuous parameters from systematic ground-based studies of the structure of blowing snow in specific fields to reduce uncertainty regarding the characteristics of blowing snow, our results point to a need to review the current understanding of the hydrological cycle.
\end{abstract}

\section{INTRODUCTION}

The sublimation of blowing snow particles is a significant process in the hydrological cycle of snow-covered plains and other regions in which most of the winter snowfall is relocated by wind (Dyunin, 1967; Tabler and Schmidt, 1972; Male, 1980; Schmidt, 1982). Thorpe and Mason (1966) performed sublimation process experiments on ice spheres, and process-based blowing snow models that incorporate sublimation have been developed (Pomeroy and others, 1993; Déry and others, 1998; Liston and Sturm, 1998; Déry and Yau, 1999; Bintanja, 2000; Xiao and others, 2000; Sugiura, 2006). Although several field studies have examined blowing-snow sublimation on a point or basin scale (Tabler, 1975; Pomeroy and others, 1997; Bintanja, 1998; Liston and Sturm, 1998; Mann and others, 2000; King and others, 2001), it is necessary to clarify the large-scale characteristics of the sublimation of blowing snow particles to better understand blowing-snow sublimation as a subprocess in the hydrological cycle of the entire cryosphere. To consider the large-scale characteristics and importance of blowing-snow sublimation in the hydrological cycle in the cryosphere, we investigated the sublimation of blowing snow particles on a global scale using global datasets and determined its distribution.

\section{DATASET AND METHODS OF ANALYSIS}

To focus our effort on global snow conditions on the land and sea using a combination of datasets that provide as fine a resolution as possible, we selected the European Centre for Medium-Range Weather Forecasts (ECMWF) re-analysis (ERA) data for 1987 and the International Satellite Land Surface Climatology Project (ISLSCP) Initiative I datasets for 1987. The elements of the ERA data for 1987 that were necessary to apply our calculation method were wind velocity at a height of $10 \mathrm{~m}$, air temperature at a height of $2 \mathrm{~m}$, skin temperature, and snow depth archived on a $2.5^{\circ} \times 2.5^{\circ}$ grid at 6 hour intervals. For the ISLSCP Initiative I datasets for 1987 , the sea-ice concentration archived on a $1^{\circ} \times 1^{\circ}$ grid at 1 month intervals was used for the calculation.

The sublimation flux of blowing snow particles, $S$ $\left(\mathrm{kg} \mathrm{m}^{-2} \mathrm{~s}^{-1}\right)$, which equals $8.6 \times 10^{4} S\left(\mathrm{~mm} \mathrm{~d}^{-1}\right)$, was calculated for every $2.5^{\circ} \times 2.5^{\circ}$ grid at 6 hour intervals. The monthly and annual mean sublimation fluxes of blowing snow particles were obtained. The sublimation flux of blowing snow particles, $S$, was defined as

$$
S=f_{\mathrm{S}} \times f_{\mathrm{OF}} \times f_{\mathrm{ST}} \times f_{\mathrm{SD}} \times f_{\mathrm{WF}},
$$

where $f_{S}$ is the main parameter used to estimate the sublimation flux of blowing snow particles, $f_{\mathrm{OF}}, f_{\mathrm{ST}}$ and $f_{\mathrm{SD}}$ are a step function of blowing-snow occurrence, skin temperature and snow depth, respectively, and $f_{\mathrm{WF}}$ is a weighting function to compensate for the difference between the ECMWF and ISLSCP gridscales.

Here $f_{\mathrm{S}}$ was defined as

$$
\begin{aligned}
f_{\mathrm{S}} & =\int_{0}^{z} \int_{0}^{\infty} C_{z} f(D)\left(\frac{\mathrm{d} m}{\mathrm{~d} t}\right) \mathrm{d} D \mathrm{~d} z \\
& =\left(1.45 \times 10^{-4} Q\right)-\left(1.40 \times 10^{-6}\right)
\end{aligned}
$$

(Schmidt, 1982, 1986),

$$
Q=1.42 u_{*}^{3.96} \quad \text { (Sugiura and others, 1998) }
$$

and

$$
u_{*}=\frac{U \kappa}{\ln \left(\frac{z}{z_{0}}\right)},
$$

where $C_{Z}$ is the number of particles in a unit volume of air at $z\left(\mathrm{~m}^{-3}\right), f(D)$ is a distribution function of particle diameter $D$, $m$ is the mass of a snow particle $(\mathrm{kg}), t$ is time $(\mathrm{s}), z$ is height (m), $Q$ is the snow transport rate $\left(\mathrm{kg} \mathrm{m}^{-1} \mathrm{~s}^{-1}\right), u_{*}$ is the friction velocity $\left(\mathrm{m} \mathrm{s}^{-1}\right), U$ is the wind velocity at a height of $10 \mathrm{~m}$ $\left(\mathrm{m} \mathrm{s}^{-1}\right), \kappa$ is von Kármán's constant $(0.4)$, and $z_{0}$ is roughness $(0.001 \mathrm{~m})$. 


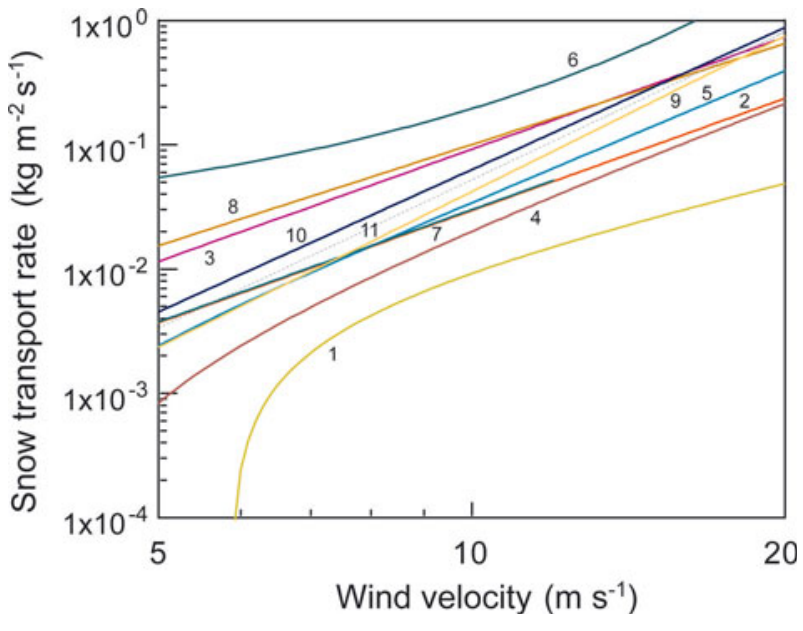

Fig. 1. The snow transport rate as a function of wind velocity at a height of $1 \mathrm{~m}$ and a roughness of $0.001 \mathrm{~m}$. 1. Khrgian in 1934 from Dyunin (1963); 2. Ivanov in 1951 from Dyunin (1963); 3. Mel'nik in 1952 from Dyunin (1963); 4. Dyunin (1963); 5. Komarov (1963); 6. Budd and others (1966); 7. Kobayashi and others (1969); 8 and 9. Takeuchi (1980); 10. Tabler (1991); 11. Sugiura and others (1998).

Because a strong dependence of the sublimation flux of blowing snow particles on the snow transport rate is expected, we used Equation (2) to describe the sublimation flux of blowing snow particles as a function of the snow transport rate.

Much effort has been made to estimate the snow transport rate as a function of wind velocity for several regions (Fig. 1; Khrgian in 1934, Ivanov in 1951 and Mel'nik in 1952 (according to Dyunin, 1963); Dyunin, 1963; Komarov, 1963; Budd and others, 1966; Kobayashi and others, 1969; Takeuchi, 1980; Tabler, 1991; Sugiura and others, 1998). There is considerable variation in the estimated snow transport rate because of differences in conditions such as topography, distance from the fetch, and temperature. Because differences in the particle collection efficiency of the instruments, most of which capture particles directly, would cause variation in the estimated snow transport rate, Sugiura and others (1998) conducted wind tunnel experiments using an optical snow particle counter without capturing particles directly, and calculated the snow transport rate as a function of the friction velocity. The

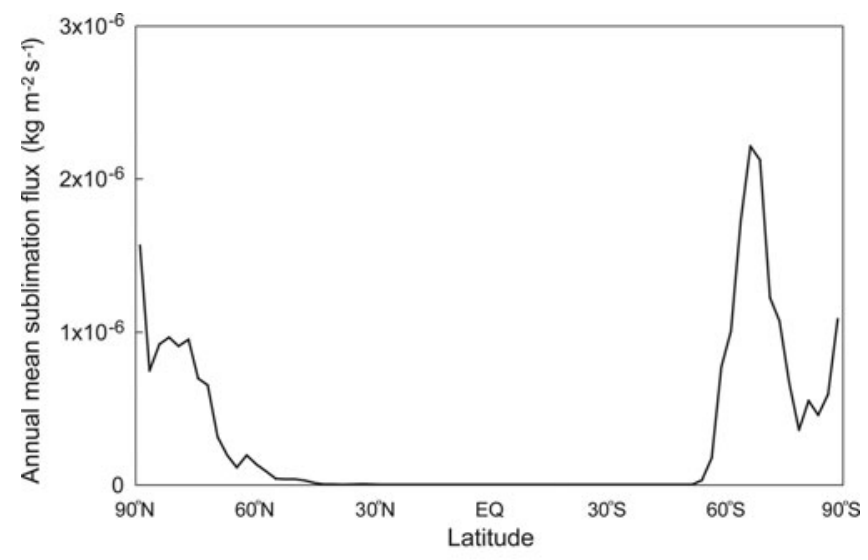

Fig. 2. Latitude distribution of the annual mean sublimation flux of blowing snow particles at $2.5^{\circ}$ latitude spacing.

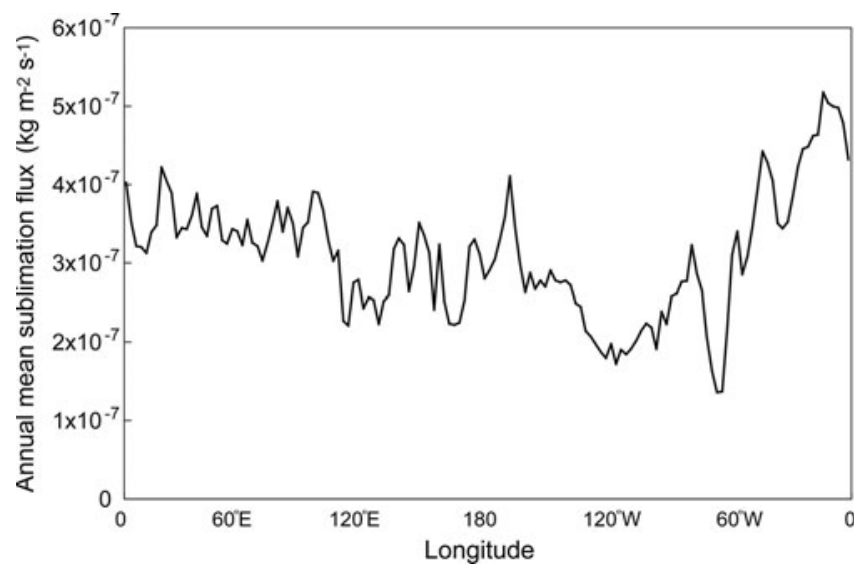

Fig. 3. Longitude distribution of the annual mean sublimation flux of blowing snow particles at $2.5^{\circ}$ longitude spacing.

validity of the snow particle counter is confirmed by field observations (Sato and others, 1993). We used the relation of Sugiura and others (1998), which gives a value that is close to the average of numerous observations (Fig. 1).

Here, $f_{\mathrm{OF}}$ was defined as

$$
\begin{gathered}
f_{\mathrm{OF}}= \begin{cases}1 & (\tau<0) \\
0 & (\tau \geq 0)\end{cases} \\
\tau=0.059072 \mathrm{AT}-U+10.35644 \\
\text { (Nishimura and Maeno, 1987), }
\end{gathered}
$$

where AT is air temperature at a height of $2 \mathrm{~m}\left({ }^{\circ} \mathrm{C}\right)$. Nishimura and Maeno (1987) estimated the blowing-snow occurrence, $\tau$, using data for several regions, including Hokkaido, Japan, (Sato, 1962) Syowa station, Antarctica, (Oura and others, 1967; JMA, 1984), Mizuho station, Antarctica, (Ohata and others, 1981) and cold wind-tunnel experiments (Maeno, 1986a, b) with an accuracy of $80.7 \%$. For example, if the air temperature at a height of $2 \mathrm{~m}$ is 0 or $-30^{\circ} \mathrm{C}$, blowing snow occurs at $10 \mathrm{~m}$ wind velocities of 10.4 or $8.6 \mathrm{~m} \mathrm{~s}^{-1}$, respectively.

Here $f_{\mathrm{ST}}$ was defined as

$$
f_{\mathrm{ST}}=\left\{\begin{array}{ll}
1 & (\mathrm{ST}<0) \\
0 & (\mathrm{ST} \geq 0)^{\prime}
\end{array},\right.
$$

where ST is skin temperature $\left({ }^{\circ} \mathrm{C}\right)$. If $U=20 \mathrm{~m} \mathrm{~s}^{-1}$ and AT $=+30^{\circ} \mathrm{C}$, Equation (5) outputs $f_{\mathrm{OF}}=1$. In this case, blowing snow occurs. Therefore, we took Equation (7) into consideration so that blowing snow might not occur.

Here $f_{\mathrm{SD}}$ was defined as

$$
f_{\mathrm{SD}}= \begin{cases}1 & (\mathrm{SD} \text { or } \mathrm{SI}>0) \\ 0 & (\mathrm{SD} \text { or } \mathrm{SI}=0)^{\prime}\end{cases}
$$

where SD is snow depth $(\mathrm{m})$ and $\mathrm{SI}$ is the sea-ice concentration (\%).

Here $f_{\mathrm{WF}}$ was defined as:

$$
f_{\mathrm{WF}}=\left\{\begin{array}{cc}
\frac{\sum\left(\frac{\mathrm{Sl}_{i}}{100} W_{i}\right)}{I} & \text { (on sea) } \\
1 & \text { (on land) }
\end{array},\right.
$$

where $i$ is the number of $1^{\circ} \times 1^{\circ}$ grids in a $2.5^{\circ} \times 2.5^{\circ}$ grid and $I$ is a constant for normalization. Because the ECMWF 


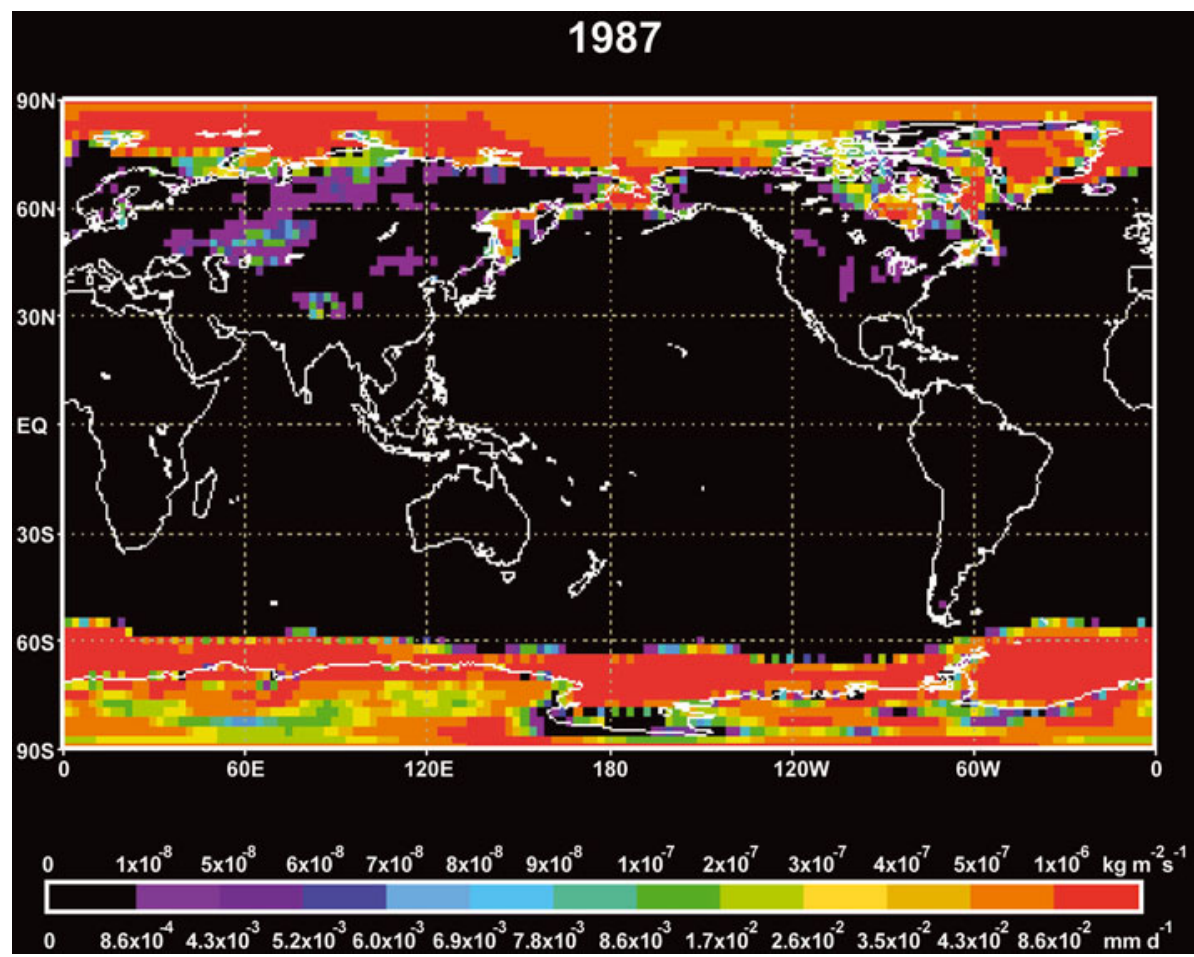

Fig. 4. Spatial distribution of the annual mean sublimation flux of blowing snow particles in each $2.5^{\circ} \times 2.5^{\circ}$ grid on a global scale.

and ISLSCP gridscales are $2.5^{\circ} \times 2.5^{\circ}$ and $1^{\circ} \times 1^{\circ}$, respectively, a weighting of $W$ was used to account for the different coverage according to grid area.

\section{RESULTS AND DISCUSSION}

We calculated the annual mean sublimation flux of blowing snow particles (Table 1). Although the coverage percentage of land and sea differs in the two hemispheres, the estimated annual mean sublimation flux was similar in the Northern and Southern Hemispheres.

We also determined the latitude distribution of the annual mean sublimation flux of blowing snow particles with a $2.5^{\circ}$ latitude spacing (Fig. 2). The annual mean sublimation flux does not increase monotonously with latitude, and ranges from 0 to $2.2 \times 10^{-6} \mathrm{~kg} \mathrm{~m}^{-2} \mathrm{~s}^{-1}\left(=1.9 \times 10^{-1} \mathrm{~mm} \mathrm{~d}^{-1}\right)$. The maximum is at $70^{\circ} \mathrm{S}$, which corresponds to the coast of Antarctica. Similarly, significant sublimation occurs along the Arctic Ocean coast between $70^{\circ}$ and $80^{\circ} \mathrm{N}$.

The longitude distribution of the annual mean sublimation flux of blowing snow particles with a $2.5^{\circ}$ longitude spacing is shown in Figure 3. The annual mean sublimation flux fluctuates with longitude, and ranges from $1.4 \times 10^{-7}\left(=1.2 \times 10^{-2} \mathrm{~mm} \mathrm{~d}^{-1}\right)$ to $5.2 \times 10^{-7} \mathrm{~kg} \mathrm{~m}^{-2} \mathrm{~s}^{-1}$ $\left(=4.5 \times 10^{-2} \mathrm{~mm} \mathrm{~d}^{-1}\right)$, with a 3.8 times difference between the maximum and minimum in the Western Hemisphere. The longitude distribution of the annual mean sublimation flux depends on the coverage rates of land and sea in the longitude zone.

The spatial distribution of the annual mean sublimation flux of blowing snow particles on a global scale $\left(2.5^{\circ} \times 2.5^{\circ}\right.$ grid) is shown in Figure 4. It is clear that sublimation in the Northern Hemisphere occurs over a wider range up to $30^{\circ} \mathrm{N}$ latitude, which includes high-elevation regions such as the Tibetan Plateau, in comparison with the Southern Hemisphere. This is because snow in the Northern Hemisphere

covers a wider area than in the Southern Hemisphere on a $2.5^{\circ} \times 2.5^{\circ}$ gridscale. In addition, it is clear that sublimation becomes more active on the high-latitude coasts, such as the coast of Antarctica, the coast of the Arctic Ocean, Bering Strait, Hudson Bay, Baffin Basin, Davis Strait, Greenland and, noteworthily, the Sea of Okhotsk which is close to the mid-latitudes. Sublimation is moderately active in west Siberia and the Tibetan Plateau because of strong wind.

The annual mean sublimation flux of the Northern Hemisphere was similar to that of the Southern Hemisphere, although the area of blowing-snow sublimation is considerably wider in the Northern Hemisphere (Table 1). One explanation may be that the area of active sublimation is distributed at high latitudes in both hemispheres, and the sublimation flux of the mid-latitudes in the Northern Hemisphere is not intense.

The annual mean sublimation flux at the boundary grid between sea ice and the sea in both hemispheres is lower than that of the grids entirely covered by sea ice (Fig. 4). This boundary grid overlaps the sea and sea ice and may be associated with the low sea-ice concentration. Based on Equations (8) and (9), blowing snow develops fully in the grid in proportion to the sea-ice concentration, even if the sea-ice concentration is low. Blowing snow develops according to the distance from the fetch. Therefore, it is thought that the

Table 1. Annual mean sublimation flux

Region Annual mean sublimation flux

$$
\mathrm{kg} \mathrm{m}^{-2} \mathrm{~s}^{-1}
$$

Northern Hemisphere Southern Hemisphere
$2.38 \times 10^{-7}\left(=2.06 \times 10^{-2} \mathrm{~mm} \mathrm{~d}^{-1}\right)$
$2.87 \times 10^{-7}\left(=2.48 \times 10^{-2} \mathrm{~mm} \mathrm{~d}^{-1}\right)$ 


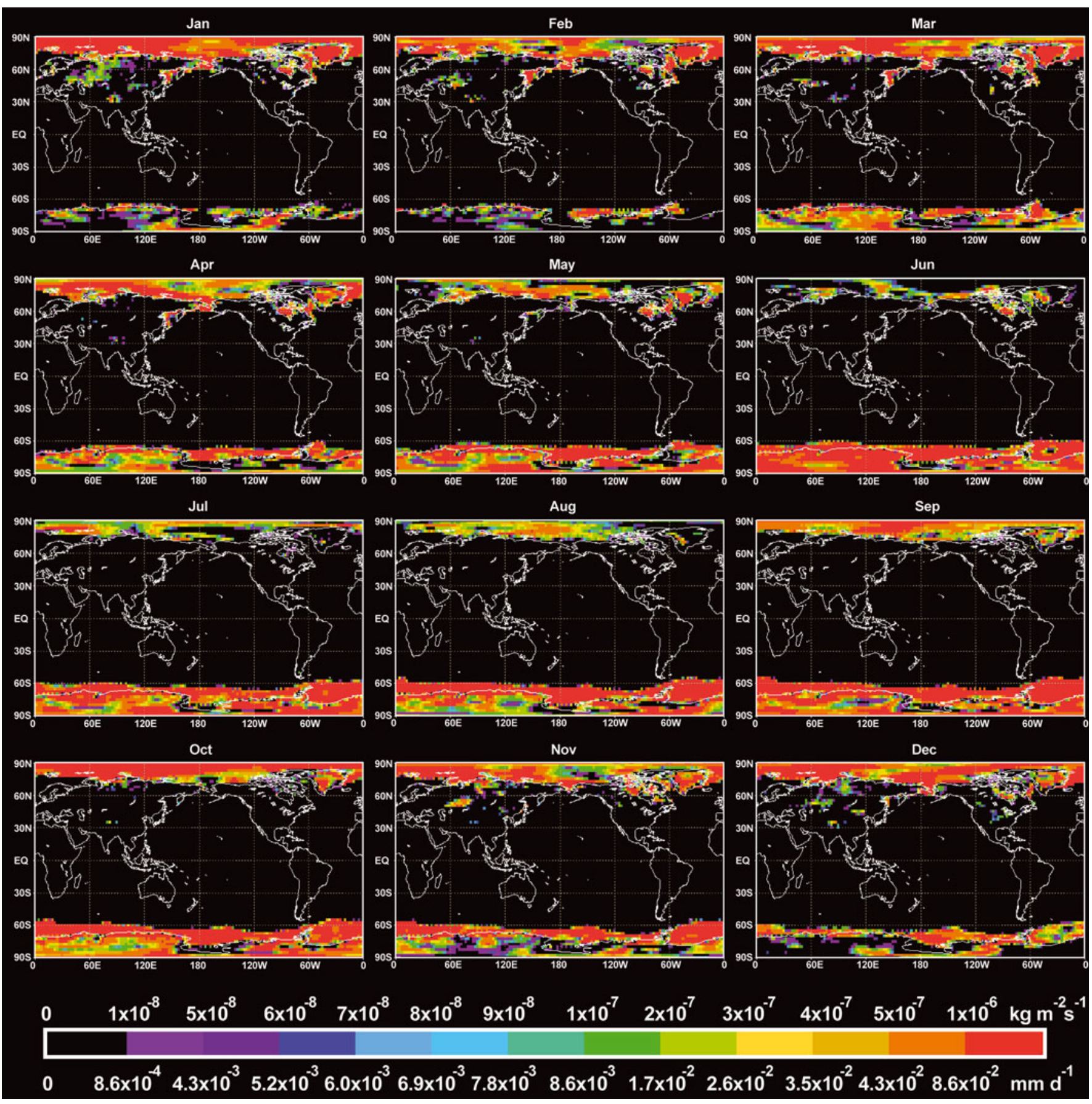

Fig. 5. Spatial distribution of the monthly mean sublimation flux of blowing snow particles in each $2.5^{\circ} \times 2.5^{\circ}$ grid on a global scale.

actual sublimation flux at the grid with low sea-ice concentration is lower because of the short distance from the fetch.

The spatial distribution of the monthly mean sublimation flux of blowing snow particles in each $2.5^{\circ} \times 2.5^{\circ}$ grid on a global scale is shown in Figure 5. The area of sublimation on the Eurasian and North American continents characteristically moves to high or low latitudes according to the season, whereas sublimation on the Antarctic coast occurs throughout the year in contrast to that in the Antarctic interior.

Liston and Sturm (1998) estimated the total winter sublimation of blowing snow particles at a snow water equivalent depth using a numerical snow-transport model based on physical quantities (SnowTran-3D) with a $20 \times 20 \mathrm{~m}$ grid spacing, a 1 day time-step, and 4 years of climate observations from September through April for the winters 1986/87, 1987/88, 1988/89 and 1989/90 at the $2 \times 3 \mathrm{~km}$ Imnavait Creek domain in the foothills north of the Brooks Range, Arctic Alaska, USA. The domain-averaged, winter-only total, and snow water equivalent quantities were tabulated. Using $0.038 \mathrm{~m}$ of the total winter sublimation data for the 1986/87 winter (8 months from September 1986 through April 1987) from Liston and Sturm (1998), the mean sublimation in snow water equivalent depth was calculated $\left(0.16 \mathrm{~mm} \mathrm{~d}^{-1}\right)$. Our value for the mean sublimation in snow water equivalent depth for the corresponding 4 months from January 1987 through April 1987 at the corresponding grid is lower $\left(2.1 \times 10^{-3} \mathrm{~mm} \mathrm{~d}^{-1}\right)$. Although only Liston and Sturm's (1998) study of a particular region over 1 year can be compared with our study and our calculation is rough, it is important to consider the difference. The snow transport rate 
in Equations (3) and (4) increases with wind velocity to the power of 3.96 , not linearly. The ECMWF $2.5^{\circ} \times 2.5^{\circ}$ grid, corresponding to the Imnavait Creek domain, comprises tundra, a hill and part of the Brooks Range. It is difficult for a large grid to describe the wind velocity distribution accurately over such an uneven surface. Consequently, fine-scale grid datasets allow more accurate estimation of the sublimation flux, and the estimated sublimation flux in high-altitude regions may increase and be emphasized more. In addition, no sublimation occurs below a threshold wind velocity derived from Equations (5) and (6), although the threshold shear velocity given by Liston and Sturm (1998) is $0.25 \mathrm{~m} \mathrm{~s}^{-1}$, which equals a $10 \mathrm{~m}$ wind velocity of $7.2 \mathrm{~m} \mathrm{~s}^{-1}$ and is weaker than the value obtained from Equations (5) and (6). Furthermore, because Equation (2) was obtained under the condition of a vertical height limit of the integration such as a height of $1 \mathrm{~m}$ from the snow surface (Schmidt, 1982), it might underestimate the amount of sublimation.

In addition to these uncertainties associated with our analyses, another uncertainty is the formation of a nearsaturated air layer. The observed relative humidity within the blowing-snow layer at Halley, Antarctica, reaches nearsaturation with respect to ice quite rapidly at the onset of a blowing-snow episode as the air becomes saturated (Mann and others, 2000). This further limits sublimation. As Mann and others (2000) discussed, the air surrounding the particles may reach near-saturation during transport across snow cover with long fetches and low ambient temperature. Finally, parameters describing the relationship between the occurrence frequency of blowing snow and the actual conditions of the snowpack on sea ice and vegetation, in addition to the formation of a near-saturated air layer, are needed for specific field observations based on systematic ground-based studies.

We have given a condensed account of blowing-snow sublimation. Our results show that the hydrological cycle of the polar coast regions and highlands in the cryosphere is characterized by blowing-snow sublimation. The general hydrological cycle is given as:

$$
P=E+R \pm \Delta S,
$$

where $P$ is precipitation, $E$ is evapotranspiration, $R$ is runoff and $S$ is storage. The blowing-snow sublimation has been estimated as $33 \%$ of the total winter $P$ by Tabler (1975) in Wyoming, USA, $20 \%$ of the total winter $P$ by Pomeroy and others (1997) at Inuvik, Canada, $9-22 \%$ of the total winter $P$ by Liston and Sturm (1998) at the Imnavait Creek domain, $10-20 \%$ of the total annual $S$ by Bintanja (1998) at D-10, a costal Antarctic location, $10 \%$ of the total annual $S$ by King and others (2001) at Halley, and $4 \%$ of the total winter $S$ by Mann and others (2000) at Halley. As has been suggested, blowing-snow sublimation is enhanced in the polar coast regions and highlands. The annual total sublimation at Halley is smaller than that at the costal Antarctic location. This is consistent with our results and suggests that evapotranspiration, $E$, in the polar coast regions and highlands should take account of blowing-snow sublimation. Future continuous work might reduce the uncertainty of various error sources in hydrological-cycle estimates for the polar coast regions and highlands.

\section{CONCLUSION}

The large-scale distribution of the sublimation of blowing snow particles can be calculated using global datasets
(ECMWF and ISLSCP for 1987). The sublimation of blowing snow particles in the Northern Hemisphere occurs over a wider range than in the Southern Hemisphere, but the annual mean sublimation flux is similar in both hemispheres. The annual mean sublimation flux does not increase monotonously with latitude, and sublimation is more active on the polar coast. The latitude of the sublimation area in the Northern Hemisphere characteristically changes greatly with the seasons. The polar coast regions and highlands are important for the hydrological cycle of the cryosphere. The reduction of the uncertainty of parameters describing the characteristics of blowing snow would require the incorporation of parameters based on systematic ground-based studies of the structure of blowing snow in specific fields, especially the relationship between the frequency of occurrence of blowing snow and the actual conditions of snow on sea ice and vegetation, in addition to the formation of a near-saturated air layer.

\section{ACKNOWLEDGEMENTS}

This research was partially supported by a Japan Society for the Promotion of Science, Grant-in-Aid for Scientific Research (C), 19540470. We thank the anonymous referees for constructive comments. Thanks are also due to the ECMWF and the NASA Goddard Space Flight Center's (GSFC) Distributed Active Archive Center (DAAC) for providing the ERA data and ISLSCP Initiative I data.

\section{REFERENCES}

Bintanja, R. 1998. The contribution of snowdrift sublimation to the surface mass balance of Antarctica. Ann. Glaciol., 27, 251-259.

Bintanja, R. 2000. Snowdrift suspension and atmospheric turbulence. I: Theoretical background and model description. Bound.-Layer Meteorol., 95(3), 343-368.

Budd, W.F., R.J. Dingle and U. Radok. 1966. The Byrd Snow Drift Project: outline and basic results. In Rubin, M.J., ed. Studies in Antarctic meteorology. Washington, DC, American Geophysical Union, 71-134. (Antarctic Research Series 9.)

Déry, S.J. and M.K. Yau. 1999. A bulk blowing snow model. Bound.-Layer Meteorol., 93(2), 237-251.

Déry, S., P. Taylor and J. Xiao. 1998. The thermodynamic effects of sublimating, blowing snow in the atmospheric boundary layer. Bound.-Layer Meteorol., 89(2), 251-283.

Dyunin, A.K. 1963. Solid flux of snow-bearing air flow. [Translated from Trudy Transportno-Energeticheskogo Instituta, 4, 71-88 [1954], by D.A. Sinclair.] NRCC Tech. Transl. 1102.

Dyunin, A.K. 1967. Fundamentals of the mechanics of snow storms. In Oura, H., ed. Physics of snow and ice. Sapporo, Hokkaido University. Institute of Low Temperature Science, 1065-1073.

Japanese Meteorological Agency (JMA). 1984. Meteorological data at the Syowa station in 1984. Antarct. Meteorol. Data, 25, 260.

King, J.C., P.S. Anderson and G.W. Mann. 2001. The seasonal cycle of sublimation at Halley, Antarctica. J. Glaciol., 47(156), 1-8.

Kobayashi, D., S. Kobayashi and N. Ishikawa. 1969. [Measurement of snow drift using parallel trenches.] Low Temp. Sci., Ser. A, 27, 99-106. [In Japanese with English summary.]

Komarov, A.A. 1963. Some rules on the migration and deposition of snow in western Siberia and their application to control measures. [Translated from Trudy Transportno-Energeticheskogo Instituta, 4, 89-97 [1954], by G. Belkov.] NRCC Tech. Transl. 1094.

Liston, G.E. and M. Sturm. 1998. A snow-transport model for complex terrain. J. Glaciol., 44(148), 498-516. 
Maeno, N. 1986. [Studies on calculation of blowing snow index (II). Railway Technical Research Institute Contract Research 1984], 43. [In Japanese.]

Maeno, N. 1987. [Studies on calculation of blowing snow index (III).] Railway Technical Research Institute Contract Research 1984], 49. [In Japanese.]

Male, D.H. 1980. The seasonal snowcover. In Colbeck, S.C., ed. Dynamics of snow and ice masses. New York, Academic Press, 305-395.

Mann, G.W., P.S. Anderson and S.D. Mobbs. 2000. Profile measurements of blowing snow at Halley, Antarctica. J. Geophys. Res., 105(D19), 24,491-24,508.

Nishimura, K. and N. Maeno. 1987. [Discriminant function analysis applied to determining an initiation condition of drifting snow.] Low Temp. Sci., Ser. A, 46, 111-117. [In Japanese with English summary.]

Ohata, T., S. Kobayashi, N. Ishikawa and S. Kawaguchi. 1981. Meteorological data at Mizuho Station, Antarctica, in 1980. JARE Data Rep., 65, 93.

Oura, H., T. Ishida, D. Kobayashi, S. Kobayashi and T. Yamada. 1967. Studies on blowing snow II. In Oura, H., ed. Physics of snow and ice. Sapporo, Hokkaido University. Institute of Low Temperature Science, 1099-1117.

Pomeroy, J.W., D.M. Gray and P.G. Landine. 1993. The prairie blowing snow model: characteristics, validation, operation. J. Hydrol., 144(1-4), 165-192.

Pomeroy, J.W., P. Marsh and D.M. Gray. 1997. Application of a distributed blowing snow model to the Arctic. Hydrol. Process., 11(11), 1451-1464.

Sato, S. 1962. [On the criterion of the railway guard patrol during a snow storm in Hokkaido.] Seppyo, J. Jpn. Soc. Snow Ice, 24(2), 21-26. [In Japanese with English summary.]

Sato, T., T. Kimura, T. Ishimaru and T. Maruyama. 1993. Field test of a new snow-particle counter (SPC) system. Ann. Glaciol., 18, 149-154.
Schmidt, R.A. 1982. Vertical profiles of wind speed, snow concentration and humidity in blowing snow. Bound.-Layer Meteorol., 23(2), 223-246.

Schmidt, R.A. 1986. Transport rate of drifting snow and the mean wind speed profile. Bound.-Layer Meteorol., 34(3), 213-241.

Sugiura, K. 2006. [A vertical multilayer energy exchange model for blowing snow.] Seppyo, J. Jpn. Soc. Snow Ice, 68(6), 549-562. [In Japanese with English summary.]

Sugiura, K., K. Nishimura, N. Maeno and T. Kimura. 1998. Measurements of snow mass flux and transport rate at different particle diameters in drifting snow. Cold Reg. Sci. Technol., 27(2), 83-89.

Tabler, R.D. 1975. Estimating the transport and evaporation of blowing snow. In Symposium on Snow Management on the Great Plains, Bismarck, North Dakota, July 1975. Proceedings. Lincoln, NE, University of Nebraska, 85-105. (Great Plains Agricultural Council Publication 73.)

Tabler, R.D. 1991. Snow transport as a function of wind speed and height. In Sodhi, D.S., ed. Cold Regions Engineering (1991). Proceedings of the Sixth International Specialty Conference. New York, American Society of Civil Engineers, 729-738.

Tabler, R.D. and R.A. Schmidt. 1972. Weather conditions that determine snow transport distances at a site in Wyoming. IAHS Publ. 107, Vol. 1 (Symposium at Banff 1972 - The Role of Snow and Ice in Hydrology), 118-127.

Takeuchi, M. 1980. Vertical profile and horizontal increase of driftsnow transport. J. Glaciol., 26(94), 481-492.

Thorpe, A.D. and B.J. Mason. 1966. The evaporation of ice spheres and ice crystals. J. Appl. Phys., 17(4), 541-548.

Xiao, J., R. Bintanja, S.J. Déry, G. Mann and P.A. Taylor. 2000. An intercomparison between three models of blowing snow in the atmospheric boundary layer. Bound.-Layer Meteorol., 97(1), 109-135. 